\title{
WHOLE GRAIN OF DIFFERENT CORN HYBRIDS IN THE FINISHING DIET OF LAMBS
}

\author{
GABRIELA AFERRI ${ }^{1}$, CRISTINA MARIA PACHECO BARBOSA ${ }^{1}$, \\ MÁRCIA MARISE DE FREITAS CAÇÃO ${ }^{1}$, AILDSON PEREIRA DUARTE ${ }^{1}$, \\ ANGÉLICA SIMONE DO CRAVO PEREIRA² e WIGNEZ HENRIQUE ${ }^{1}$
}

\author{
I Agência Paulista de Tecnologia dos Agronegócios - APTA \\ gabriela@apta.sp.gov.br,cristina@apta.sp.gov.br,marcia@apta.sp.gov.br,aildson@apta.sp.gov.br,wignez@apta.sp.gov.br. \\ ${ }^{2}$ Universidade de São Paulo-USP, angelpereira@usp.br.
}

Revista Brasileira de Milho e Sorgo, v.18, n.2, p. 290-298, 2019

\begin{abstract}
The objective of this study was to compare whole grains of different corn hybrids in the finishing diet of lambs in terms of apparent digestibility, ingestive behavior and feedlot performance. Twenty-four crossbred lambs housed in individual pens were used. The animals were fed $7.35 \%$ hay and $92.65 \%$ concentrate (dry matter basis) containing $23.05 \%$ of a protein supplement plus $69.6 \%$ whole corn grains of the hybrids P3862, P4285 or Status for 72 days and were then slaughtered. The final body weight $(40.82 \mathrm{~kg})$ or daily weight gain $(251 \mathrm{~g})$ did not differ between lambs fed the different hybrids. Daily dry matter intake, expressed as percentage of live weight, was lower in the group fed the Status hybrid and intermediate in the group fed the P3862 hybrid. The Status hybrid resulted in lower digestibility of dietary crude protein, dry matter, and organic matter. There was no difference in hot carcass weight $(19.8 \mathrm{~kg})$, hot carcass yield $(48.6 \%)$ or ingestive behavior between animals fed the different hybrids. Whole grains of the corn hybrids P3862 and P4285 are more indicated for fattening lambs fed with high-concentrate diets.
\end{abstract}

Key words: ingestive behavior, performance, digestibility, sheep, Zea mays

\section{GRÃOS INTEIROS DE DIFERENTES HÍBRIDOS DE MILHO NA ALIMENTAÇÃO DE CORDEIROS EM TERMINAÇÃO}

\begin{abstract}
RESUMO - O objetivo foi comparar grãos de diferentes híbridos de milho na dieta de cordeiros quanto à digestibilidade aparente, comportamento ingestivo e desempenho em confinamento. Foram utilizados 24 cordeiros cruzados, alojados em baias individuais e alimentados com $7,35 \%$ de feno e $92,65 \%$ de concentrado na matéria seca, contendo: $23,05 \%$ de suplemento proteico mais $69,60 \%$ de grãos inteiros de milho dos híbridos P3862, P4285 ou Status, por 72 dias, e depois abatidos. O peso corporal final (média de 40,82 kg) e o ganho de peso diário (média de $251 \mathrm{~g}$ ) não diferiram entre os cordeiros alimentados com os diferentes híbridos. A ingestão diária de matéria seca em porcentagem do peso vivo foi de 3,41\% nos animais alimentados com Status e de 3,60\% nos animais alimentados com P3862, e estatisticamente diferentes. O híbrido Status apresentou menor digestibilidade da proteína bruta, matéria seca e orgânica da dieta. O peso de carcaça quente (média de 19,8 kg) e o rendimento de carcaça quente (média de 48,6\%) e o comportamento ingestivo não diferiram entre os animais alimentados com os diferentes híbridos. Grãos inteiros dos híbridos de milho P3862 e P4285 são mais indicados para alimentar cordeiros em terminação recebendo dietas com alta proporção de concentrado, com base na sua maior eficiência de conversão e digestibilidade.
\end{abstract}

Palavras-chave: comportamento ingestivo, desempenho, digestibilidade, ovinos, Zea mays 
The feedlot finishing system of lambs using high-concentrate diets is a technology increasingly adopted by Brazilian sheep farmers (Gallo et al., 2014), since it provides benefits such as higher weight gain and fast finishing. Among the ingredients used in this concentrate, corn grain is the main energy feed source.

Whole corn grain can be used in lamb diets, accounting for up to $80 \%$ of dry matter (Crane et al., 2014), because this ingredient is more economical, not adding processing expenses, and is therefore more convenient and practical for the producer (Oliveira et al., 2015). In these cases, the corn hybrid used and its nutritional features have an additional economic value since they interfere directly with feedlot profitability.

One of the features that interfere with the quality of corn grains is their texture (Pereira et al., 2004), which can be flint, semi-flint, semi-dent, or dent. The harder the kernel, the higher the quantity of vitreous endosperm; on the other hand, the more dent the kernel, the higher the quantity of floury endosperm. Considering that vitreous endosperm exhibits certain resistance to digestion, the ratio between vitreous and floury endosperm can directly affect the digestibility of corn and utilization by the animal (Cantarelli et al., 2007). Indirectly, kernel density indicates the variation in the proportion of corneous and starchy endosperm in the grain (Delalibera et al., 2008).

The grains of most corn cultivars commercially available in Brazil have a smooth or semi-dent crown and generally a dense and hard endosperm (Oliveira et al., 2015). Thus, knowledge of the performance of different corn hybrids used for feeding feedlot animals permits breeders to choose the ideal plant genotype in order to obtain the best economic outcome of their activity.

Based on these premises, the objective of the study was to evaluate the apparent digestibility, performance and ingestive behavior of feedlot lambs fed high-concentrate diets containing whole grains of three different corn hybrids.

\section{Material and Methods}

Twenty-four uncastrated, male, crossbred lambs of the paternal Dorper breed, weaned at a mean age of 70 days and a mean weight of 29.76 $\pm 1.8 \mathrm{~kg}$, were used. The animals were kept in feedlots in suspended individual pens with a slatted floor and were randomly assigned to receive one of three commercial whole grain corn hybrids: P3862 (Pioneer - semi-flint), P4285 (Pioneer - flint), or Status (Syngenta - flint), characterized in Table 1.

The animals were submitted to a period of adaptation of 14 days, receiving a diet with a concentrate/roughage ratio of 50:50 and 75:25 in the first and second week, respectively. The final proportion used was 92.75:7.25 (Table 1). The diet was formulated to attend nutritional requirements of lambs with weight gain of $250 \mathrm{~g}$ /day (National Research Council, 2007) and consisted $7.25 \%$ of coast cross hay grounded plus concentrate with $69.7 \%$ corn, $13.84 \%$ soy hulls, $5.8 \%$ soybean meal, $1.32 \%$ urea, $1 \%$ mineral salt, $0.59 \%$ limestone, and $0.5 \%$ ammonium chloride. Coast cross hay (Cynodon dactylon) was used as roughage. Feed was offered twice a day (7:30 and 16:00 h) as complete ration with $10 \%$ leftovers. The leftovers were removed and weighed daily.

After adaptation to the diet, feces collection bags were attached to the animals for the determination of apparent digestibility of the diets. The animals remained with the bags for 10 days, including 5 days for adaptation and 5 days for the collection of feces, feed offered and leftovers. The fecal samples were 
weighed daily, sampled, and frozen. At the end of the sampling period, the samples of each animal were pooled and analyzed regarding dry matter, mineral matter and crude protein content according to the Association of Official Analytical Chemists (1995) and regarding neutral and acid detergent fiber content according to Silva and Queiroz (2002).

Performance was evaluated over a period of 48 days, in addition to the days for the determination of nutrient digestibility, with weight recording at the beginning and end of the experimental period after a 14-h fast from solids. The feed efficiency was determined by the relation between weight gain in kilograms and dry matter in kilograms.

In the middle of the performance-testing period, the animals were observed individually by a trained team for the evaluation of ingestive behavior. Individual behaviors were recorded at intervals of 10 minutes over a period of $24 \mathrm{~h}$ for determination of the time spent eating, ruminating and idling as described by Johnson and Combs (1991). During night observation of the animals, the environment was

Table 1. Bromatological composition on a dry matter (DM) basis and physical characterization of the corn hybrid grains and nutritional composition of the diets

\begin{tabular}{|c|c|c|c|}
\hline \multirow{2}{*}{ Variable } & \multicolumn{3}{|c|}{ Corn hybrid } \\
\hline & P3862 & $\mathrm{P} 4285$ & Status \\
\hline \multicolumn{4}{|l|}{ Bromatological composition } \\
\hline Dry matter, \% & 89.84 & 89.97 & 90.28 \\
\hline Crude protein, $\%$ DM & 8.44 & 10.02 & 7.36 \\
\hline Ether extract, \% DM & 4.42 & 4.78 & 3.52 \\
\hline Mineral matter, \% DM & 1.39 & 1.52 & 1.48 \\
\hline Acid detergent fiber, $\%$ DM & 3.02 & 3.66 & 3.39 \\
\hline Neutral detergent fiber, \% DM & 11.08 & 12.73 & 12.36 \\
\hline Cellulose, \% DM & 2.36 & 3.08 & 2.63 \\
\hline Lignin, \% DM & 0.78 & 0.62 & 0.84 \\
\hline Hemicellulose, \% DM & 8.07 & 9.08 & 8.97 \\
\hline \multicolumn{4}{|l|}{ Physical characterization } \\
\hline Floating kernels ${ }^{1}, \%$ & 45 & 34 & 18 \\
\hline Crown appearance & Semi-hard & Hard & Hard \\
\hline \multicolumn{4}{|l|}{ Diet composition (\% DM) } \\
\hline Dry matter, $\%$ & 89.9 & 90.0 & 90.2 \\
\hline Crude protein, $\% \mathrm{DM}$ & 12.7 & 13.8 & 12.0 \\
\hline Acid detergent fiber, \% DM & 11.2 & 11.7 & 11.5 \\
\hline Neutral detergent fiber, \% DM & 23.1 & 24.3 & 24.0 \\
\hline Metabolizable energy $^{2}, \mathrm{Mcal} / \mathrm{kg}$ & 3.69 & 3.68 & 3.87 \\
\hline
\end{tabular}


illuminated artificially and the animals were adapted for 5 days to the artificial illumination of the barn. Rumination efficiency was calculated as dry matter intake (g)/rumination time (h), and intake efficiency was calculated as dry matter (g)/eating time (h). The number of chewing cycles and the time spent ruminating each rumen bolus were determined with a digital timer (Bürger et al., 2000). For this purpose, three rumen boluses were observed at three different times of the day (10-12:00, 14-16:00, and 20-22:00 h).

The animals were slaughtered after a 14-h fast from solids and the carcass was weighed one hour after slaughter.

A completely randomized design consisting of three treatments and eight replications were used. The data were submitted to analysis of variance and means were compared by the Tukey test, adopting a level of significance of $5 \%$. The PROC GLM procedure of the SAS package (SAS Institute, Inc., Cary, NC, USA) was used for statistical analysis.

\section{Results and Discussion}

Weight gain or dry matter intake did not differ among treatments, but the ratio of these traits showed that the use of different hybrids altered feed efficiency (Table 2). An increase in feed efficiency was observed for animals fed the diet containing hybrid P3862, classified as semi-flint. Feed efficiency decreased in animals receiving the diet containing the Status hybrid, classified as hard and denser.

The group receiving hybrid P4285, also classified as hard but less dense than Status, exhibited intermediate feed efficiency values and similar to the other two hybrids. Hardness is relatively similar for materials with hard and semi-hard texture and is therefore not an efficient factor to measure nutritional differences between corn hybrids. This is because the evaluation of crown appearance is not an efficient method to predict kernel density (Duarte et al., 2007). The differences in weight traits and dry matter intake found in the present study would indicate that density is more valuable to predict nutritional value than texture classification (Table 2).

Carcass weight or yield did not differ between animals fed the different corn hybrids studied. In addition, to promoting rapid finishing of the animals, the high concentrate content of the diet was probably the factor that most influenced carcass yield. However, according to Moreno et al. (2011), the ratio of roughage to concentrate and the type of roughage influence the digestive tract content of lambs, indirectly affecting carcass yield.

The use of the Status hybrid with denser kernels in the diet caused a reduction in apparent digestibility of crude protein, dry matter, and organic matter (Table 2). The differences in dry matter and organic matter digestibility between the diets containing the hybrids classified as hard, P4285 and Status, reinforce the fact that crown appearance does not necessarily indicate kernel density. It is interesting to consider the hardness of the whole grain of corn in diets with high proportion of this food, since they can directly influence the efficiency of the use of the diet, despite the efficient chewing of the lambs. This is due to the need of different forces for fragmentation when compressing kernels with different densities, with this requirement being proportional to the amount of corneous endosperm (Delalibera et al., 2008).

The diets containing the higher digestibility hybrids, P3862 and P4285, also provided better feed efficiency, although only hybrid P3862 was different from the Status hybrid (Table 2). Probably, starch digestion of hybrid P3862 had a lower impact on 
Table 2. Performance and carcass traits of lambs fed different corn hybrids, apparent digestibility of the diets, and ingestive behavior

\begin{tabular}{|c|c|c|c|c|c|}
\hline \multirow{2}{*}{ Trait } & \multicolumn{3}{|c|}{ Corn hybrid } & \multirow{2}{*}{$\mathrm{CV}^{1}$} & \multirow{2}{*}{$\mathrm{P}^{2}$} \\
\hline & P3862 & P4285 & Status & & \\
\hline \multicolumn{6}{|l|}{ Performance } \\
\hline Initial body weight, kg & 29.37 & 29.66 & 30.24 & 8.07 & 0.7656 \\
\hline Final body weight, kg & 40.37 & 40.36 & 41.74 & 0.18 & 0.7042 \\
\hline Daily weight gain, kg & 0.292 & 0.222 & 0.239 & 27.63 & 0.1367 \\
\hline \multicolumn{6}{|l|}{ Daily dry matter intake } \\
\hline $\mathrm{kg}$ & 0.984 & 0.905 & 1.056 & 12.83 & 0.0793 \\
\hline$\%$ body weight & $3.60^{\mathrm{ab}}$ & $3.89^{\mathrm{a}}$ & $3.41^{\mathrm{b}}$ & 9.53 & 0.0367 \\
\hline Feed efficiency, $\mathrm{kg} / \mathrm{kg}^{3}$ & $0.294^{\mathrm{a}}$ & $0.240^{\mathrm{ab}}$ & $0.226^{\mathrm{b}}$ & 21.51 & 0.0501 \\
\hline \multicolumn{6}{|l|}{ Carcass } \\
\hline Hot carcass weight, kg & 20.25 & 19.01 & 19.98 & 10.46 & 0.4619 \\
\hline Hot carcass yield, $\%$ & 50.51 & 47.15 & 48.15 & 11.31 & 0.4685 \\
\hline \multicolumn{6}{|l|}{ Apparent digestibility (\%) } \\
\hline Dry matter & $81.84^{\mathrm{a}}$ & $81.56^{\mathrm{a}}$ & $78.17^{\mathrm{b}}$ & 3.78 & 0.0456 \\
\hline Organic matter & $83.19^{\mathrm{a}}$ & $83.25^{\mathrm{a}}$ & $79.70^{\mathrm{b}}$ & 3.69 & 0.0450 \\
\hline Crude protein & $71.08^{\mathrm{a}}$ & $71.06^{\mathrm{a}}$ & $62.97^{\mathrm{b}}$ & 7.99 & 0.0095 \\
\hline Acid detergent fiber & 52.20 & 49.92 & 44.91 & 18.65 & 0.2856 \\
\hline Neutral detergent fiber & 54.80 & 53.01 & 48.71 & 13.23 & 0.2167 \\
\hline \multicolumn{6}{|l|}{ Behavior } \\
\hline Intake, h/day & 2.88 & 3.31 & 3.06 & 19.74 & 0.3726 \\
\hline Rumination, h/ day & 4.10 & 4.41 & 4.54 & 27.89 & 0.7612 \\
\hline Other activities, $\mathrm{min} /$ day & 17.02 & 12.26 & 16.40 & 8.27 & 0.5139 \\
\hline Chewing $^{4}$, No./bolus & 58.00 & 64.00 & 65.00 & 13.10 & 0.2578 \\
\hline Rumination time $^{5}$, s/bolus & 35.00 & 37.00 & 37.00 & 18.58 & 0.8808 \\
\hline Total chewing time ${ }^{6}, \mathrm{~h}$ & 6.98 & 7.73 & 7.60 & 18.44 & 0.5139 \\
\hline \multicolumn{6}{|l|}{ Efficiency $(\mathrm{g} / \mathrm{h})$} \\
\hline Rumination of dry matter & 246 & 212 & 260 & 30.07 & 0.4016 \\
\hline Intake of dry matter & 352 & 287 & 352 & 22.32 & 0.1526 \\
\hline
\end{tabular}

${ }^{\mathrm{a}, \mathrm{b}}$ Means in the same row followed by the same superscript letter do not differ by the Tukey test at the $5 \%$ level. ${ }^{1}$ Coefficient of variation. ${ }^{2}$ Probability. ${ }^{3} \mathrm{~kg}$ weight gain/kg ingested dry matter. ${ }^{4}$ Chews per food bolus. ${ }^{5}$ Time spent ruminating per food bolus. ${ }^{6}$ Intake plus rumination.

the ruminal environment, since no difference in the digestibility of the protein fraction was observed between hybrids P3862 and P4285.
The lowest digestibility of protein was probably related to vitreous endosperm. This kind of endosperm contains bonds which are difficult 
to digest by the animal due to a continuous and abundant protein matrix with a larger size and quantity of protein bodies associated with compact and polygonal starch granules (Pereira et al., 2004). Although hybrids P4285 and Status are classified as hard, the difference in kernel density observed by the quantity of floating kernels (34\% and 19\% for P4285 and Status, respectively) indicates different proportions of endosperm and its association with the protein fraction (Table 1).

Differences in the chemical composition and physical structure of the starch present in the endosperm of kernels directly influence how ruminants digest them, especially the protein content in the vitreous endosperm matrix (Philippeau et al., 1999). It is not expected that the protein sources used in the concentrate (urea, hull, and soybean meal) have interfered with the performance of lambs, since the animals were fed a high-concentrate diet (Queiroz et al., 2008). Thus, the protein bound to the vitreous endosperm of the kernel was likely responsible for the differences in starch digestibility between the different corn hybrids, influencing feed efficiency by altering the sites of starch digestion and consequently the type of substrate absorbed by the digestive tract of the animals (Huhtanen \& Sveinbjörnsson, 2006; Banchero et al., 2015). This effect is important in intensive systems of lamb fattening with highconcentrate diets, which require some control of starch digestion to minimize the incidence of ruminal acidosis (Askar et al., 2008).

Crude protein, dry matter and organic matter digestibility were the most important parameters to differentiate the hybrids tested. The digestibility of neutral or acid detergent fibers were not different statistically among diets showing low influence on the performance of lambs fed high-concentrate diets
(Mendes et al., 2010).

The use of different corn hybrids in the diets did not alter the ingestive behavior of the animals (Table 2). The ingestive behavior of feedlot animals is limited to the choice of food offered and how easily it can be ingested (Catanese et al., 2013). In addition, dietary offering stimulus can increase the time spent eating after supply of the food (Cardoso et al., 2006).

The ingestive behavior, intake and rumination efficiency are directly related to the energy content of the diet (Fontenele et al., 2011). This fact was probably the determinant factor for the lack of observation of differences in these efficiencies between corn hybrids, since the metabolizable energy of the diets was similar for hybrids P3862, P4285 and Status (3.69, 3.68 and $3.87 \mathrm{Mcal} / \mathrm{kg}$, respectively).

The data obtained in this study indicate that more research on this subject are needed, as will enable to identify maize cultivars that are better suited to different types of diets for lambs, especially those used in feedlot with high whole grain proportions.

\section{Conclusions}

The classification of corn based on appearance in flint, semi-flint, semi-dent or dent is not an adequate tool to identify superior hybrids for the diet of fattening lambs when offered as whole grains. Whole grains of the P3862 hybrid, classified as semi-flint, and of the P4285 hybrid, classified as flint, are more indicated for the feeding of fattening lambs receiving a high-concentrate diet than the Status hybrid, also classified as flint, based on differences on feed efficiency. 


\section{References}

ASSOCIATION OF OFFICIAL ANALYTICAL CHEMISTS. Official methods of analysis. 16 ed. Washington, 1995. v. 2.

ASKAR, A. R.; GUADA, J. A.; GONZÁLEZ, J. M.; VEJA, A.; FONDEVILA, M. Rumen digestion and microbial protein synthesis by growing lambs fed high-concentrate diets: effects of cereal processing and animal age. Animal Feed Science and Technology, v. 142, p. 29-305, 2008. Available in: <http://www.sciencedirect.com/science/ article/pii/S0301622605003854>. Access in: 26 mar. 2018.

DOI: 10.1016/j.anifeedsci.2007.09.003.

BANCHERO, G. E.; MILTON, J. T. B.; LINDSAY, D. R.; MARTIN, G. B.; QUINTANS, G. Colostrum production in ewes: a review of regulation mechanisms and of energy supply. Animal, v. 9, p. 831-837, 2015. Available in: <http:// journals.cambridge.org/action/displayAbstract?fromPa$\mathrm{ge}=$ online $\&$ aid $=9617243 \&$ fileId $=$ S1751731114003243 $>$. Access in: 21 jul. 2018.

DOI: $10.1017 /$ S1751731114003243.

BÜRGER, P. J.; PEREIRA, J. C.; QUEIROZ, A. C. Comportamento ingestivo em bezerros holandeses alimentados com dietas contendo diferentes níveis de concentrado. Revista Brasileira de Zootecnia, v. 29, p. 236-242, 2000. Available in: <http://www.scielo.br/pdf/ rbz/v29n1/5754.pdf>. Access in: 1 abr. 2018.

DOI: $10.1590 /$ S1516-35982000000100031.

CANTARELLI, V. S.; FIALHO, E. T.; SOUSA, R. V.; FREITAS, R. T. F.; LIMA, J. A. F. Composição química, vitreosidade e digestibilidade de diferentes híbridos de milho para suínos. Ciência e Agrotecnologia, v. 31, p. 860-864, 2007. Available in: <http://www.scielo.br/pdf/ cagro/v31n3/a36v31n3.pdf $>$. Access in: 1 abr. 2018. DOI: $10.1590 /$ S1413-70542007000300036.

CARDOSO, A. R.; CARVALHO, S.; GALVANI, D. B.; PIRES, C. C.; GASPERIN, B. G.; GARCIA, R. P. A. Comportamento ingestivo de cordeiros alimentados com dietas contendo diferentes níveis de fibra em detergente neutro. Ciência Rural, v. 36, p. 604-609, 2006. Available in: $<$ http://www.scielo.br/scielo.php?script=sci arttext\&pid=S0103-84782006000200038\&lng=pt\&nrm=i so\&tlng $=\mathrm{pt}>$. Access in: 1 abr. 2018.

DOI: $10.1590 / \mathrm{S} 0103-84782006000200038$.

CATANESE, F.; OBELAR, M.; VILLALBA, J. J.; DISTEL, R. A. The importance of diet choice on stress-related responses by lambs. Applied Animal Behaviour Science, v. 148, p. 37-45, 2013. Available in: $\quad<$ http://www.sciencedirect.com/science/article/pii/ S0168159113001792>. Access in: 21 jul. 2018.

DOI: 10.1016/j.applanim.2013.07.005.

CRANE, A. R.; REDDEN, R. R.; BERG, P. B.; SCHAUER, C. S. Effects of diet particle size and lasalocid on growth, carcass traits, and $\mathrm{N}$ balance in feedlot lambs. Sheep \& Goat Research Journal, v. 29, p. 17-23, 2014. Available in: <http://amhealthmaster.http.internapcdn. net/AMHealthMaster/DOCUMENT/SheepUSA/SGRJ_ V29_17-23_Crane_12-14.pdf $>$. Access in: 1 jul. 2018.

DELALIBERA, H. C.; WEIRICH NETO, P. H.; COLET, M. J.; GARBUIO, P. W.; SVERZUT, C. B. Resistência de grãos de milho à ruptura por compressão. Ciência Rural, v. 38, p. 2493-2497, 2008. Available in: $\quad<$ http://www.scielo.br/scielo.php?script=sci arttext\&pid $=$ S0103-84782008000900012 $>$. Access in: 2 abr. 2018.

DOI: $10.1590 / \mathrm{S} 0103-84782008000900012$.

DUARTE, A. P.; CARVALHO, C. R. L.; CAVICHIOLI, J. C. Produtividade, aparência, densidade e suscetibilidade à quebra dos grãos em híbridos de milho safrinha. Revista Brasileira de Milho e Sorgo, v. 6, p. 174-185, 2007. Available in: <http://rbms.cnpms.embrapa.br/index.php/ ojs/article/view/223/224>. Access in: 2 abr. 2018.

DOI: 10.18512/1980-6477/rbms.v6n2p174-185.

FONTENELE, R. M.; PEREIRA, E. S.; CARNEIRO, M. S. S.; PIMENTEL, P. G.; CÂNDIDO, M. J. D.; REGADAS FILHO, J. G. L. Consumo de nutrientes e comportamento ingestivo de cordeiros da raça Santa Inês alimentados com rações com diferentes níveis de energia metabolizável. Revista Brasileira de Zootecnia, v. 40, n. 6, p. 1280- 
1286, 2011. Available in: <http://www.scielo.br/pdf/rbz/ v40n6/17.pdf>. Access in: 2 abr. 2018.

DOI: $10.1590 / \mathrm{S} 1516-35982011000600017$.

GALLO, S. B.; MERLIN, F. A.; MACEDO, C. M.; SILVEIRA, R. D. O. Whole grain diet for feedlot lambs. Small Ruminant Research, v. 120, p. 185-188, 2014. Available in: <http://www.sciencedirect.com/science/ article/pii/S0921448814001539>. Access in: 21 jul. 2018. DOI: 10.1016/j.smallrumres.2014.05.014.

HUHTANEN, P.; SVEINBJÖRNSSON, J. Evaluation of methods for estimating starch digestibility and digestion kinetics in ruminants. Animal Feed Science and Technology, v. 130, p. 95-113, 2006. Available in: $\quad<$ http://www.animalfeedscience.com/article/S03778401(06)00030-7/pdf $>$. Access in: 19 jul. 2018.

DOI: 10.1016/j.anifeedsci.2006.01.021.

JOHNSON, T. R.; COMBS, D. K. Effects of prepartum diet, inert rumen bulk, and dietary polythylene glicol on dry matter intake of lactating dairy cows. Journal of Dairy Science, v. 74, p. 933-944, 1991. Available in: $<$ http://www.journalofdairyscience.org/article/S00220302(91)78243-X/pdf >. Access in: 2 abr. 2018.

DOI: $10.3168 /$ jds.S0022-0302(91)78243-X.

MENDES, C. Q.; TURINO, V. F.; SUSIN, I.; PIRES, A. V.; MORAIS, J. B.; GENTIL, R. S. Comportamento ingestivo de cordeiros e digestibilidade dos nutrientes de dietas contendo alta proporção de concentrado e diferentes fontes de fibra em detergente neutro. Revista Brasileira de Zootecnia, v. 39, p. 594-600, 2010. Available in: $<$ http://www.scielo.br/scielo.php?script=sci arttext\&pid $=$ S1516-35982010000300019 $>$. Access in: 2 abr. 2018. DOI: 10.1590/S1516-35982010000300019.

MORENO, G. M. B.; SILVA SOBRINHO, A. G.; LEÃO, A. G.; PEREZ, H. L.; LOUREIRO, C. M. B.; PEREIRA, G. T. Rendimento dos componentes não-carcaça de cordeiros alimentados com silagem de milho ou cana-de-açúcar e dois níveis de concentrado. Revista Brasileira de Zootecnia, v. 40, p. 2878-2885, 2011. Available in: <http://www.revista. sbz.org.br/artigo/index.php?artigo $=66477>$. Access in: 26 mar. 2018. DOI: 10.1590/S1516-35982011001200035.
NATIONAL RESEARCH COUNCIL. Nutrient requirements of small ruminants: sheep, goats, cervids, and new world camelids. Washington: National Academy Press, 2007. 384 p.

OLIVEIRA, L. S.; MAZON, M. R.; CARVALHO, R. F.; PESCE, D. M. C.; SILVA, S. L.; GALLO, S. B.; LEME, P. R. Effects of processing corn on the carcass traits and meat quality of feedlot lambs. Tropical Animal Health Production, v. 47, p. 883-887, 2015. Available in: <http:// link.springer.com/article/10.1007/s11250-015-0803-x>. Access in: 21 jul. 2018. DOI: 10.1007/s11250-015-0803-x.

PEPLINSKI, A. J.; PAULSEN, M. R.; ANDERSON, R. A.; KWOLEK, W. F. Physical, chemical, and dry-milling characteristics of corn of varying density and breakage susceptibility. Cereal Chemistry, v. 69, n. 4, p. 397-400, 1992. Available in: <http://www.aaccnet.org/publications/cc/ backissues/1992/Documents/69_397.pdf >.Access in:2abr. 2018.

PEREIRA, M. N.; PINHO, R. G.; BRUNO, R. G. S.; CALESTINE, G. A. Ruminal degradability of hard or soft texture corn grain at three maturity stages. Scientia Agricola, v. 61, p. 358-363, 2004. Available in: <http:// www.scielo.br/pdf/sa/v61n4/22150.pdf $>$. Access in: 2 abr. 2018. DOI: $10.1590 / \mathrm{S} 0103-90162004000400002$.

PHILIPPEAU, C.; MONREDON, F. D.; MICHALETDOREAU, B. Relationship between ruminal starch degradation and the physical characteristics of corn grain. Journal of Animal Science, v. 77, p. 238-243, 1999. DOI: $10.2527 / 1999.771238 x$.

QUEIROZ, M. A. Á.; SUSIN, I.; PIRES, A. V.; MENDES, C. Q.; GENTIL, R. S.; ALMEIDA, O. C.; AMARAL, R. C.; MOURÃO, G. B. Desempenho de cordeiros e estimativa da digestibilidade do amido de dietas com diferentes fontes proteicas. Pesquisa Agropecuária Brasileira, v. 43, n. 9, p. 1193-1200, 2008. Available in: <http://www.scielo.br/ pdf/pab/v43n9/14.pdf $>$. Access in: 2 abr. 2018.

DOI: 10.1590/S0100-204X2008000900014.

SILVA, D. J.; QUEIROZ, A. C. Análise de alimentos: métodos químicos e biológicos. 3. ed. Viçosa, MG: Universidade Federal de Viçosa, 2002. 235 p. 
WEISS, W. P.; CONRAD, H. R.; ST. PIERRE, N. R. A theoretically-based model for predicting total digestible nutrient values of forages and concentrates. Animal Feed Science and Technology, v. 39, p. 95-110, 1992. Available

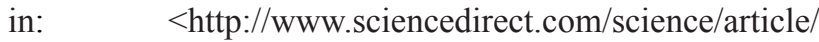
pii/0377840192900344> . Access in: 26 mar. 2018.

DOI: 10.1016/0377-8401(92)90034-4. 